\title{
PENINGKATKAN KEMAMPUAN PENYELENGGARAAN LAYANAN BIMBINGAN DAN KONSELING BAGI GURU KELAS DI GUGUS IX DHANDHANGGULA UPTD DIKPORA JEBRES SURAKARTA MELALUI SUPERVISI KELOMPOK
}

\author{
Tri Hartanti \\ UPTD Dinas Dikpora Kecamatan Laweyan \\ 3hartanti.solo@gmail.com
}

\begin{abstract}
The research is aimed at: 1) describing the implementation of directive supervision to improve the classroom teachers in providing the guidance and counseling; and 2) improving the classroom teacher's ability in providing the guidance and counseling for the teachers at Gugus IX Dhandhanggula UPTD Dikpora Kecamatan Jebres of Surakarta through the directive suprevision.The research is an action research. The research was done at Gugus IX Dhandhanggula UPTD Dikpora Kecamatan Jebres of Surakarta in academic year 2012/2013. The subject of the research were 12 clasroom teachers. The data collecting method were done by using interview and observation. The data analysis was done by using path model from Kemmis and Taggart.The research concludes that: 1) the directive supervision to improve the classroom teachers ability in providing the guidance and counseling was done as follows: (a) the supervisor socialized the supervision program to the teachers; (b) the supervisor arranged the supervision schedule; (c) the supervisor provided the supervision materials; (d) the supervisor provided the guidance and counseling simulation; and (e) the supervisor assessed the teachers' ability in providing the guidance and counseling; and 2) the directive supervision was effective in improving the classroom teachers ability in providing the guidance and counseling. It is demonstrated with the improvement in the teachers' scores in each cycle.
\end{abstract}

Keywords: academic supervision, group model, guidance and counseling

Abstrak: Penelitian ini bertujuan untuk: 1) mendeskripsikan pelaksanaan supervisi kelompok metode direktif guna meningkatkan kemampuan guru kelas dalam layanan bimbingan dan konseling; dan 2) meningkatkan kemampuan guru kelas dalam layanan bimbingan dan konseling pada guru kelas di Gugus IX Dhandhanggula UPTD Dikpora Kecamatan Jebres Kota Surakarta melalui supervisi kelompok metode direktif.Jenis penelitian adalah Penelitian Tindakan. Penelitian dilakukan di Gugus IX Dhandhanggula UPTD Dikpora Kecamatan Jebres Kota Surakarta tahun pelajaran 2012/2013. Subyek penelitian ini adalah guru Kelas IV sampai dengan kelas VI SD dengan jumlah 12 orang guru. Teknik pengumpulan data dilakukan dengan teknik wawancara dan observasi. Teknik analisis data dilakukan dengan model alur dari Kemmis dan Taggart.Hasil penelitian menyimpulkan bahwa: 1) Pelaksanaan supervisi kelompok metode direktif dalam meningkatkan layanan bimbingan dan konseling bagi guru kelas adalah sebagai berikut: a) Pengawas menyampaikan sosialisasi tentang program supervisi kepada guru; b) Pengawas menyusun jadwal pelaksanaan program supervisi; c) Pengawas menyampaikan materi program layanan bimbingan dan konseling; d) Pengawas melakukan simulasi layanan bimbingan dan konseling; 
dan e) Pengawas melakukan penilaian terhadap kemampuan guru dalam melakukan layanan bimbingan dan konseling;dan 2) Supervisi kelompok metode direktif efektif dalam meningkatkan layanan bimbingan dan konseling bagi guru kelas. Hal ini ditunjukkan dengan meningkatnya kemampuan guru dalam setiap aspek penilaian pada setiap siklus tindakan yang dilakukan.

Kata Kunci: supervisi akademik, metode kelompok, layanan bimbingan dan konseling

\section{Pendahuluan}

Keberadaan konselor dalam sistem pendidikan nasional dinyatakan dalam bentuk salah satu kualifikasi pendidik yang sejajar dengan kualifikasi guru, dosen, pamong, dan tutor. Hal ini tertuang dalam pasal 1 ayat (6) Undang Undang Nomor 20 tahun 2003 tentang Sistem Pendidikan Nasional.Hal ini mengindikasikan bahwa keberadaan konselor dalam sistem persekolahan disetarakan dengan profesi guru.

Di tingkat Sekolah Dasar, guru pembimbing dirangkap tugas oleh guru kelas. Dengan demikian, maka kemampuan dalam penguasaan penyelenggaraan layanan bimbingan dan konseling masih dipertanyakan. Untuk itu diperlukan pembinaan bagi guru kelas dalam menyelenggarakan layanan bimbingan dan konseling di sekolah.

Hal yang sama terjadi pada Sekolah Dasar di Gugus IX Dhandhanggula UPTD Dikpora Kecamatan Jebres Kota Surakarta. Guru kelas di sekolah-sekolah tersebut harus merangkap sebagai guru pembimbing. Di sisi lain, semua guru kelas yang ada belum dibekali pelatihan bimbingan konseling yang memadai. Dengan demikian maka kemampuan dalam menyelenggarakan pelayanan bimbingan dan konseling masih terkesan seadanya.

Salah satu usaha yang dapat dilakukan untuk meningkatkan kemampuan guru kelas dalam melaksanakan bimbingan dan konseling adalah dengan memberikan pembinaan. Pembinaan kepada guru tersebut dapat dilakukan oleh Pengawas Sekolah melalui kegiatan supervisi yang dilakukan.

Alternatif pemecahan atas masalah peningkatan pemahaman dalam pelayanan bimbingan dan konseling bagi guru kelas adalah melalui kegiatan supervisi kelompok dengan metode direktif. Kegiatan supervisi kelompok dengan metode direktif yang dilakukan oleh kepala sekolah diharapkan dapat meningkatkan pemahaman guru kelas tentang pelaksanaan pelayanan bimbingan dan konseling kepada siswa.

Berdasarkan uraian di atas selanjutnya dapat dirumuskan hipotesis tindakan dan tujuan penelitian. Adapun tujuan penelitian ini adalah sebagai berikut: 1) Untuk mendeskripsikan pelaksanaan supervisi kelompok metode direktif guna meningkatkan kemampuan guru kelas dalam layanan bimbingan dan konseling; dan 2) Untuk meningkatkan kemampuan guru kelas dalam layanan bimbingan dan konseling pada guru kelas di Gugus IX Dhandhanggula UPTD Dikpora Kecamatan Jebres Kota Surakarta melalui supervisi kelompok metode direktif.

\section{Metode}

Sesuai dengan permasalahan yang diteliti, maka penelitian tindakan ini dilaksanakan di Gugus IX Dhandhanggula UPTD Dikpora Kecamatan Jebres Kota Surakarta.Adapun waktu penelitian dilaksanakan pada semester gasal tahun pelajaran 2012/2013.

Penelitian dilakukan selama 8 (delapan) minggu, yaitu dimulai pada minggu I bulan September 2012 hingga minggu ke I bulan Nopember 2012.

Subjek dalam penelitian ini adalah guru kelas IV sampai dengan kelas VI SD di Gugus IX Dhandhanggula UPTD Dikpora Kecamatan Jebres Kota Surakarta, yang terdiri dari 12 orang guru. Adapun objek 
penelitian berupa peningkatan pemahaman tentang penyelenggaraan layanan bimbingan dan konseling bagi guru kelas SD di Gugus IX Dhandhanggula UPTD Dikpora Kecamatan Jebres Kota Surakarta melalui kegiatan supervisi kelompok dengan metode direktif.

Desain penelitian tindakan yang dinilai akurat dalam mencapai tujuan tersebut adalah model desain alur PTK secara umum yang memiliki ciri khas menggunakan model siklus.Setiap siklus terdiri dari dua atau tiga tindakan pembelajaran, sedangkan setiap tindakan mencakup empat tahapan kegiatan, yaitu perencanaan, pelaksanaan tindakan, observasi, dan refleksi-evaluasi.

Penelitian dilakukan dengan dua siklus tindakan. Setiap siklus diakhiri dengan tahapan refleksi. Data yang diperoleh dianalisis dan dimaknai dengan menggunakan analisis deskriptif prosentase dan untuk mengetahui perubahan hasil tindakan dilakukan dengan membandingkan hasil supervisi pada tindakan siklus sebelumnya.

Teknik pengambilan data dilakukan dengan cara observasi dan dokumen. Observasi dilakukan terhadap praktek pelaksanaan pelayanan BK yang dilakukan guru dengan empat indikator yang meliputi: (a) kemampuan merancang program layanan bimbingan dan konseling, (b) kemampuan mengimplementasikan program layanan bimbingan dan konseling yang komprehensif, (c) kemampuan penilaian proses dan hasil kegiatan layanan bimbingan dan konseling, dan (d) penguasaan konsep dan praksis asesmen untuk memahami kondisi, kebutuhan, dan masalah konselii. Adapun teknik dokumen dilakukan dengan memeriksa dokumen program rencana bimbingan konseling yang disusun oleh guru.

Teknik analisis data dilakukan dengan mengikuti prosedur analisis model alur dari Kemmis dan Taggart. Teknik ini intinya adalah mengidentifikasi perkembangan dan perubahan subjek setelah subjek diberi perlakuan khusus atau dikondisikan pada situasi tertentu dengan tindakan dalam kurun waktu tertentu dan berulang-ulang sampai program dinyatakan berhasil.

Untuk mengukur keberhasilan tindakan, peneliti merumuskan indikator-indikator ketercapaian program supervisi kelompok model direktif tentang bimbingan dan konseling pada guru kelas SD Gugus IX Dhandhanggula UPTD Dikpora Kecamatan Jebres Kota Surakarta. Indikator keberhasilan tindakan penelitian ini dirumuskan sebagai berikut:

1. Program tindakan supervisi kelompok direktif tentang program layanan bimbingan dan konseling bagi guru dinyatakan berhasil apabila 70\% subjek sudah menguasai kemampuan dalam melaksanakan program layanan bimbingan dan konseling.

2. Guru dinyatakan mampu untuk melaksanakan layanan bimbingan dan konseling apabila sudah mencapai skor nilai 70 dalam setiap aspek penilaian.

\section{Hasil dan Pembahasan}

Data kondisi awal kemampuan guru dalam layanan bimbingan dan konseling diperoleh dari penilaian yang dilakukan pengawas terhadap program layanan bimbingan dan konseling yang disusun guru sebelum dilaksanakan kegiatan supervisi.

Berdasarkan hasil-hasil analisis dokumen perencanaan dan simulasi praktek tindakan pada tabel di atas, dapat diketahui bahwa kemampuan guru dalam merancang materi secara klasikal masih dianggap belum berhasil.Hal ini ditunjukkan dengan hasil penilaian pada seluruh aspek penilaian di mana rata-rata yang diperoleh 62.08.Nilai rata-rata yang diperoleh $<70$.

Penilaian pada aspek perencanaan program (Kolom A) menunjukkan bahwa rata-rata skor yang diperoleh guru adalah 64.17.Nilai ini masih di bawah standar yang ditetapkan sebesar 70. Jumlah guru yang sudah memperoleh skor dengan kategori baik, yaitu dengan skor $\geq 70$, baru mencapai 3 orang guru $(25.0 \%)$, sisanya sebanyak 9 orang $(75.0 \%)$ masih belum dapat menyusun 
program perencanaan Layanan BK dengan baik.

Penilaian pada aspek implementasi program layanan bimbingan dan konseling (Kolom B) menunjukkan bahwa jumlah guru yang sudah mencapai kategori baik, yaitu dengan nilai $\geq 70$, sebanyak 1 orang atau $8,33 \%$. Sedangkan guru yang masih belum berhasil menguasai kemampuan untuk mengimplementasikan program layanan bimbingan dan konseling adalah 11 orang atau 91,67\%. Dengan demikian secara klasikal guru belum dapat dianggap mampu untuk mengimplementasikan program layanan bimbingan dan konseling.
Penilaian pada aspek menilai proses dan hasil kegiatan program layanan bimbingan dan konseling (Kolom C) menunjukkan bahwa belum ada guru yang kategori baik, yaitu dengan nilai $\geq 70$.Penilaian pada aspek penguasaan konsep dan praksis asesmen untuk memahami kondisi, kebutuhan, dan masalah konselii (Kolom D) menunjukkan bahwa belum ada guru kategori baik, yaitu dengan nilai $\geq 70$.Data kemampuan guru dalam layanan bimbingan dan konseling pada kondisi awal dapat disajikan ke dalam tabel berikut ini.

Tabel 1

Hasil Penilaian Kemampuan Guru dalam Layanan Bimbingan dan Konseling Kondisi Awal

\begin{tabular}{|c|c|c|c|c|c|c|c|}
\hline \multirow{2}{*}{ No. } & \multirow{2}{*}{$\begin{array}{c}\text { Inisial Nama } \\
\text { Subjek }\end{array}$} & \multicolumn{4}{|c|}{ Aspek Penilaian } & \multirow{2}{*}{ Total } & \multirow{2}{*}{ Rata $^{2}$} \\
\hline & & $\mathbf{A}$ & B & $\mathbf{C}$ & D & & \\
\hline 1. & HRN & 70 & 70 & 65 & 65 & 270 & 67.5 \\
\hline 2. & SRY & 70 & 65 & 65 & 65 & 265 & 66.25 \\
\hline 3. & SLM & 65 & 65 & 60 & 60 & 250 & 62.5 \\
\hline 4. & SWD & 70 & 65 & 60 & 60 & 255 & 63.75 \\
\hline 5. & AGS & 65 & 60 & 60 & 60 & 245 & 61.25 \\
\hline 6. & SKY & 60 & 60 & 60 & 60 & 240 & 60 \\
\hline 7. & STS & 60 & 60 & 60 & 60 & 240 & 60 \\
\hline 8. & STH & 65 & 65 & 60 & 60 & 250 & 62.5 \\
\hline 9. & STR & 60 & 60 & 60 & 60 & 240 & 60 \\
\hline 10. & SUP & 60 & 60 & 60 & 60 & 240 & 60 \\
\hline 11. & SPR & 65 & 60 & 60 & 60 & 245 & 61.25 \\
\hline 12. & RSY & 60 & 60 & 60 & 60 & 240 & 60 \\
\hline \multicolumn{2}{|c|}{ Jumlah } & 770 & 750 & 730 & 730 & 2980 & 248.33 \\
\hline \multicolumn{2}{|c|}{ Rata-rata } & 64.17 & 62.50 & 60.83 & 60.83 & 248.33 & 62.08 \\
\hline
\end{tabular}

Tindakan kegiatan supervisi kelompok model direktif pada siklus I dilaksanakan dalam empat tahap kegiatan. Tahapan kegiatan tersebut meliputi perencanaan, pelaksanaan, observasi, dan refleksi. Perencanaan program supervisi kelompok model direktif dengan materi tentang layanan bimbingan dan konseling dilakukan dengan memperhatikan hasil identifikasi permasalahan yang dilakukan serta mempersiapkan perangkat yang diperlukan.
Pelaksanaan kegiatan supervisi kelompok model direktif dengan materi tentang layanan bimbingan dan konseling pada tindakan Siklus I dilakukan pada hari Sabtu, 29 September 2012.Kegiatan supervisi dilaksanakan dalam bentuk office conference di sekolah inti, yaitu di SD Negeri Bulukantil No. 150 Kecamatan Jebres.

Adapun kegiatan yang dilakukan pada tindakan Siklus I adalah sebagai berikut: 1) Pengawas menyampaikan materi tentang 
penyelenggaraan program layanan bimbingan dan konseling bagi siswa, yang mencakup perancangan program layanan bimbingan dan konseling, implementasi layanan program, penilaian proses dan hasil kegiatan layanan bimbingan dan konseling, dan konsep serta praksis asesmen untuk memahami kondisi, kebutuhan, dan masalah konselii; 2) Para guru kelas melakukan diskusi dan simulasi penyelenggaraan program layanan bimbingan dan konseling; dan 3) Pengawas memberikan tes kemampuan dalam penyelenggaraan layanan bimbingan dan konseling baik secara tertulis mapun praktek langsung.

Observasi dilakukan

selama berlangsungnya kegiatan tindakan supervisi kelompok.Berdasarkan hasil-hasil analisis dokumen perencanaan dan simulasi praktek tindakan pada tabel di atas, dapat diketahui bahwa kemampuan guru dalam pelaksanaan layanan bimbingan dan konseling mengalami peningkatan dibandingkan dengan kondisi awal.Hal ini ditunjukkan dengan meningkatnya skor pada setiap aspek penilaian yang dilakukan.Kemampuan guru dalam merancang materi secara klasikal masih dianggap belum berhasil.Hal ini ditunjukkan dengan hasil penilaian pada seluruh aspek penilaian di mana rata-rata yang diperoleh baru mencapai 66.88 atau < 70.Penilaian pada aspek perencanaan program (Kolom A) menunjukkan bahwa rata-rata skor yang diperoleh guru sudah dapat dikategorikan baik, Hal ini ditunjukkan dengan skor ratarata pada aspek perencanaan $\geq 70$, yaitu 70.83 . Jumlah guru yang sudah memperoleh skor dengan kategori baik, yaitu dengan skor $\geq$ 70 , pada aspek perencanaan sudah mencapai 9 orang guru $(75.0 \%)$, sisanya sebanyak 3 orang $(25.0 \%)$ masih belum dapat menyusun program perencanaan Layanan BK dengan baik.

Penilaian pada aspek implementasi program layanan bimbingan dan konseling (Kolom B) menunjukkan bahwa jumlah guru yang sudah mencapai kategori baik, yaitu dengan nilai $\geq 70$, sebanyak 6 orang atau 50,00\%. Sedangkan guru yang masih belum berhasil menguasai kemampuan untuk mengimplementasikan program layanan bimbingan dan konseling adalah 6 orang atau $50,00 \%$. Skor rata-rata pada aspek ini $<70$, yaitu baru mencapai 67.92.Penilaian pada aspek menilai proses dan hasil kegiatan program layanan bimbingan dan konseling (Kolom C) menunjukkan bahwa jumlah guru yang memperoleh skor dengan kategori baik, yaitu dengan nilai $\geq 70$, adalah sebanyak 2 orang atau $16.67 \%$. Skor rata-rata yang diperoleh pada aspek ini $<70$, yaitu baru mencapai 65.42.

Penilaian pada aspek penguasaan konsep dan praksis asesmen untuk memahami kondisi, kebutuhan, dan masalah konselii (Kolom D) menunjukkan bahwa guru yang memperoleh skor dengan kategori baik, yaitu dengan nilai $\geq 70$, adalah sebanyak 2 orang atau $16.67 \%$. Skor rata-rata yang diperoleh pada aspek ini $<70$, yaitu baru mencapai 63.33.Data kemampuan guru dalam layanan bimbingan dan konseling pada tindakan Siklus I dapat disajikan ke dalam tabel 2.

Berdasarkan hasil tes dan non tes yang diperoleh pada tindakan siklus sebelumnya dapat diperoleh hasil refleksi untuk perbaikan pada tindakan siklus berikutnya. Refleksi yang diperoleh dari tindakan Siklus I adalah sebagai berikut:

1. Supervisi kelompok metode direktif dapat meningkatkan kemampuan guru dalam penyelenggaraan layanan bimbingan dan konseling. Hal ini ditunjukkan dengan meningkatnya kemampuan guru dalam dalam penyelenggaraan layanan bimbingan dan konseling pada setiap aspek penilaian.

2. Peningkatan kemampuan guru dalam penyelenggaraan layanan bimbingan dan konseling belum optimal. Hal ini ditunjukkan dengan skor rata-rata yang diperoleh masih di bawah skor dengan kategori baik, yaitu dengan skor $\geq 70$.

3. Kelemahan yang masih ada pada guru dalam penyelenggaraan layanan bimbingan dan konseling adalah pada aspek implementasi dan penilaian proses 
layanan bimbingan dan konseling, serta penguasaan konsep dan praksis asesmen untuk memahami kebutuhan, dan masalah konselii. Untuk itu fokus perbaikan pada tindakan siklus II adalah pada aspek-aspek tersebut.

Tabel 2

Hasil Penilaian Kemampuan Guru dalam Layanan Bimbingan dan Konseling Tindakan Siklus I

\begin{tabular}{|c|c|c|c|c|c|c|c|}
\hline \multirow{2}{*}{ No. } & \multirow{2}{*}{$\begin{array}{c}\text { Inisial Nama } \\
\text { Subjek }\end{array}$} & \multicolumn{4}{|c|}{ Aspek Penilaian } & \multirow{2}{*}{ Total } & \multirow{2}{*}{ Rata $^{2}$} \\
\hline & & $\mathbf{A}$ & B & $\mathrm{C}$ & D & & \\
\hline 1. & HRN & 75 & 75 & 70 & 70 & 290 & 72.50 \\
\hline 2. & SRY & 75 & 70 & 70 & 70 & 285 & 71.25 \\
\hline 3. & SLM & 75 & 70 & 65 & 65 & 275 & 68.75 \\
\hline 4. & SWD & 75 & 70 & 65 & 65 & 275 & 68.75 \\
\hline 5. & AGS & 75 & 70 & 65 & 65 & 275 & 68.75 \\
\hline 6. & SKY & 70 & 65 & 65 & 65 & 265 & 66.25 \\
\hline 7. & STS & 70 & 70 & 65 & 60 & 265 & 66.25 \\
\hline 8. & STH & 70 & 65 & 65 & 60 & 260 & 65.00 \\
\hline 9. & STR & 65 & 65 & 65 & 60 & 255 & 63.75 \\
\hline 10. & SUP & 65 & 65 & 60 & 60 & 250 & 62.50 \\
\hline 11. & SPR & 70 & 65 & 65 & 60 & 260 & 65.00 \\
\hline 12. & RSY & 65 & 65 & 65 & 60 & 255 & 63.75 \\
\hline \multicolumn{2}{|c|}{ Jumlah } & 850 & 815 & 785 & 760 & 3210 & 267.50 \\
\hline \multicolumn{2}{|c|}{ Rata-rata } & 70.83 & 67.92 & 65.42 & 63.33 & 267.50 & 66.88 \\
\hline
\end{tabular}

Perencanaan tindakan pada Siklus II didasarkan pada hasil refleksi tindakan Siklus I. Berdasarkan hasil refleksi dari tindakan siklus sebelumnya, maka tindakan pada Siklus II difokuskan pada aspek implementasi dan penilaian proses layanan bimbingan dan konseling, serta penguasaan konsep dan praksis asesmen untuk memahami kebutuhan, dan masalah konselii.

Pelaksanaan kegiatan supervisi kelompok model direktif dengan materi tentang layanan bimbingan dan konseling pada tindakan Siklus II dilakukan sebagai berikut: 1) Pengawas menyampaikan materi tentang langkah-langkah implementasi layanan program, penilaian proses dan hasil kegiatan layanan bimbingan dan konseling, dan konsep serta praksis asesmen untuk memahami kondisi, kebutuhan, dan masalah konselii; 2) Guru melakukan simulasi program layanan bimbingan dan konseling dengan dipandu pengawas; dan 3) Pengawas memberikan tes kemampuan dalam penyelenggaraan layanan bimbingan dan konseling baik secara tertulis mapun praktek langsung.
Berdasarkan hasil-hasil pada tindakan Siklus II, dapat diketahui bahwa kemampuan guru dalam merancang materi secara klasikal sudah dianggap berhasil. Hal ini ditunjukkan dengan hasil aspek penilaian pada kolom A di mana seluruh guru sudah mencapai skor dengan kategori baik, yaitu dengan skor $\geq 70$. Skor rata-rata kemampuan guru pada aspek ini adalah sebesar 75,00.

Penilaian pada aspek implementasi program layanan bimbingan dan konseling (Kolom B) menunjukkan bahwa kemampuan guru sudah dianggap baik dalam menguasai kemampuan tersebut. Hal ini ditunjukkan dengan hasil aspek penilaian pada kolom B di mana seluruh guru sudah mencapai skor dengan kategori baik, yaitu dengan skor $\geq 70$. Skor rata-rata kemampuan guru pada aspek ini adalah sebesar 70.42 .

Penilaian pada aspek menilai proses dan hasil kegiatan program layanan bimbingan dan konseling (Kolom C) menunjukkan bahwa jumlah guru yang sudah memperoleh 
skor dengan kategori baik, yaitu dengan skor $\geq 70$, sudah mencapai 10 orang atau $83.33 \%$. Skor rata-rata kemampuan guru pada aspek ini adalah sebesar 69.17. Penilaian pada aspek penguasaan konsep dan praksis asesmen untuk memahami kondisi, kebutuhan, dan masalah konselii (Kolom D) menunjukkan bahwa jumlah guru yang sudah mencapai skor dengan kategori baik, yaitu dengan skor $\geq 70$, adalah sebanyak 10 orang atau $83.33 \%$. Skor rata-rata kemampuan guru pada aspek ini adalah sebesar 69.17.

Hasil penilaian pada seluruh aspek menunjukkan bahwa skor rata-rata yang diperoleh guru adalah sebesar 70.94 atau sudah dapat dikategorikan dengan klasifikasi berkemampuan baik. Dengan demikian maka guru kelas IV sampai dengan kelas VI di Gugus IX Dhandhanggula UPTD Dikpora Kecamatan Jebres sudah dianggap memiliki kemampuan yang baik dalam penyelenggaraan layanan bimbingan dan konseling.

Data kemampuan guru dalam layanan bimbingan dan konseling pada tindakan Siklus II dapat disajikan ke dalam tabel berikut ini.

Tabel 3

Hasil Penilaian Kemampuan Guru dalam Layanan Bimbingan dan Konseling Tindakan Siklus II

\begin{tabular}{|c|c|c|c|c|c|c|c|}
\hline \multirow{2}{*}{ No. } & \multirow{2}{*}{$\begin{array}{c}\text { Inisial Nama } \\
\text { Subjek }\end{array}$} & \multicolumn{4}{|c|}{ Aspek Penilaian } & \multirow{2}{*}{ Total } & \multirow{2}{*}{ Rata $^{2}$} \\
\hline & & $\mathbf{A}$ & B & $\mathrm{C}$ & D & & \\
\hline 1. & HRN & 80 & 75 & 70 & 70 & 295 & 73.75 \\
\hline 2. & SRY & 80 & 70 & 70 & 70 & 290 & 72.50 \\
\hline 3. & SLM & 80 & 70 & 70 & 70 & 290 & 72.50 \\
\hline 4. & SWD & 80 & 70 & 70 & 70 & 290 & 72.50 \\
\hline 5. & AGS & 80 & 70 & 70 & 70 & 290 & 72.50 \\
\hline 6. & SKY & 75 & 70 & 70 & 70 & 285 & 71.25 \\
\hline 7. & STS & 75 & 70 & 70 & 70 & 285 & 71.25 \\
\hline 8. & STH & 70 & 70 & 70 & 70 & 280 & 70.00 \\
\hline 9. & STR & 70 & 70 & 70 & 70 & 280 & 70.00 \\
\hline 10. & SUP & 70 & 70 & 65 & 65 & 270 & 67.50 \\
\hline 11. & SPR & 70 & 70 & 70 & 70 & 280 & 70.00 \\
\hline 12. & RSY & 70 & 70 & 65 & 70 & 275 & 68.75 \\
\hline \multicolumn{2}{|c|}{ Jumlah } & 900 & 845 & 830 & 830 & 3405 & 284.17 \\
\hline \multicolumn{2}{|c|}{ Rata-rata } & 75.00 & 70.42 & 69.17 & 69.17 & 283.75 & 70.94 \\
\hline
\end{tabular}

Berdasarkan hasil tes dan non-tes pada tindakan Siklus II maka dapat dihasilkan refleksi tindakan Siklus II sebagai berikut:

1. Supervisi kelompok metode direktif pada tindakan Siklus II dapat meningkatkan kemampuan guru dalam melaksanakan program layanan bimbingan dan konseling. Hal ini ditunjukkan dengan meningkatnya skor kemampuan guru dalam setiap aspek penilaian dibandingkan dengan kondisi sebelumnya.

2. Tindakan Siklus II berhasil meningkatkan kemampuan guru kelas dalam penyelenggaraan layanan bimbingan dan konseling. Hal ini ditunjukkan dengan jumlah guru yang sudah mempunyai kemampuan menyelenggarakan layanan bimbingan dan konseling dengan kategori baik, yaitu dengan skor $\geq 70$, sudah mencapai $83.33 \%$ dari jumlah guru.

Hipotesis tindakan yang menyatakan bahwa "supervisi kelompok metode direktif dapat meningkatkan kemampuan guru dalam menyelenggarakan layanan bimbingan dan konseling bagi guru kelas di 
Gugus IX Dhandhanggula UPTD Dikpora Kecamatan Jebres Kota Surakarta" terbukti kebenarannya.Hal ini ditunjukkan dengan meningkatnya skor kemampuan guru dalam setiap aspek penilaian pada setiap siklus tindakan yang dilakukan.

Kemampuan guru dalam penyelenggaraan layanan bimbingan dan konseling pada kondisi awal masih jauh dari optimal.Hal ini ditunjukkan dengan skor ratarata $\leq 70$.Jumlah guru dengan kemampuan penyelenggaraan layanan bimbingan dan konseling kategori baik, yaitu dengan skor $\geq$ 70, belum ada.

Berpijak dari kondisi tersebut, pengawas sekolah, berupaya meningkatkan kemampuan guru kelas dalam penyelenggaraan layanan bimbingan dan konseling. Upaya yang dilakukan adalah dengan cara supervisi kelompok metode direktif. Supervisi dilaksanakan dengan office conference di sekolah inti dengan jadwal yang tidak mengganggu kegiatan belajar siswa.

Upaya yang dilakukan pengawas pada tindakan Siklus I berhasil meningkatkan kemampuan guru kelas dalam penyelenggaraan layanan bimbingan dan konseling.Hal ini ditunjukkan dengan meningkatnya skor yang diperoleh guru pada setiap aspek penilaian.

Peningkatan yang diperoleh pada tindakan Siklus I dirasa belum optimal.Hal ini diindikasikan dengan belum tercapainya indikator keberhasilan tindakan berupa skor rata-rata kemampuan guru kelas dalam penyelenggaraan layanan bimbingan dan konseling $\geq 70$, dan jumlah guru dengan kemampuan penyelenggaraan layanan bimbingan dan konseling dengan kategori baik (skor $\geq 70$ ) adalah $\geq 75 \%$ dari jumlah guru.

Mengacu pada hasil refleksi tindakan Siklus I, pengawas melakukan perbaikan pada supervisi tindakan Siklus II.Perbaikan yang dilakukan adalah dengan memberikan bimbingan pada aspek yang masih menjadi kelemahan guru.Perbaikan pada tindakan Siklus II disertai dengan simulasi penyelenggaraan layanan bimbingan dan konseling.Langkah ini cukup efektif dalam meningkatkankemampuanbahwakemampuan guru kelas dalam menyelenggarakan layanan bimbingan dan konseling.Data peningkatan kemampuan penguasaan layanan bimbingan dan konseling pada Siklus I dan Siklus II dapat disajikan sebagai berikut.

Tabel 4

Peningkatan Kemampuan Guru dalam Penyelenggaraan Layanan BK Kondisi Awal - Tindakan Siklus II

\begin{tabular}{|c|c|c|c|c|c|c|c|}
\hline \multirow{2}{*}{ No. } & \multirow{2}{*}{$\begin{array}{l}\text { Kategori Ke- } \\
\text { mampuan }\end{array}$} & \multicolumn{2}{|c|}{ Awal } & \multicolumn{2}{|c|}{ Siklus I } & \multicolumn{2}{|c|}{ Siklus II } \\
\hline & & Jumlah & $\%$ & Jumlah & $\%$ & Jumlah & $\%$ \\
\hline 1. & $\begin{array}{l}\text { Baik (Skor } \geq \\
70)\end{array}$ & 0 & 0.00 & 2 & 16.67 & 10 & 83.33 \\
\hline 2. & $\begin{array}{l}\text { Belum Baik } \\
(\text { Skor < 70) }\end{array}$ & 12 & 100.00 & 10 & 83.33 & 2 & 16.67 \\
\hline \multicolumn{2}{|c|}{ Jumlah } & 12 & 100.00 & 12 & 100.00 & 12 & 100.00 \\
\hline \multicolumn{2}{|c|}{ Skor terendah } & \multicolumn{2}{|c|}{60.00} & \multicolumn{2}{|c|}{62.50} & \multicolumn{2}{|c|}{67.50} \\
\hline \multicolumn{2}{|c|}{ Skor Tertinggi } & \multicolumn{2}{|c|}{67.50} & \multicolumn{2}{|c|}{72.50} & \multicolumn{2}{|c|}{73.75} \\
\hline \multicolumn{2}{|c|}{ Skor Rata-rata } & \multicolumn{2}{|c|}{62.08} & \multicolumn{2}{|c|}{66.88} & \multicolumn{2}{|c|}{70.94} \\
\hline
\end{tabular}

Data peningkatan jumlah guru dengan kemampuan penyelenggaraan layanan bimbingan dan konseling pada tabel di atas dapat disajikan ke dalam diagram sebagai berikut. 


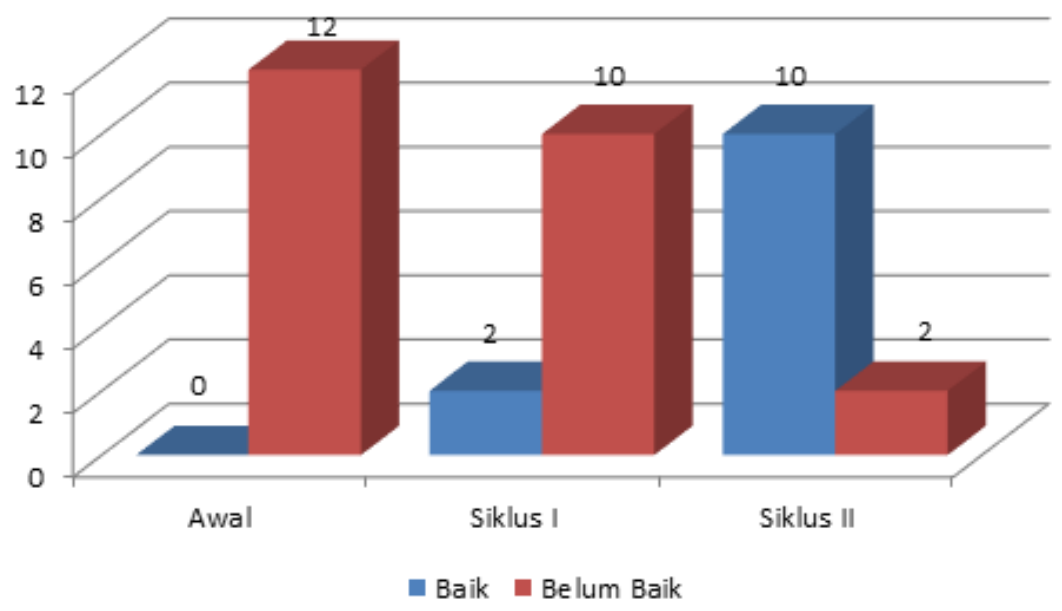

Gambar 1 Diagram Peningkatan Jumlah Guru dengan Kemampuan Penyelenggaraan Layanan Bimbingan dan Konseling

Data peningkatan kemampuan guru tindakan Siklus II dapat disajikan ke dalam dalam penyelenggaraan layanan bimbingan diagram sebagai berikut dan konseling dari kondisi awal hingga

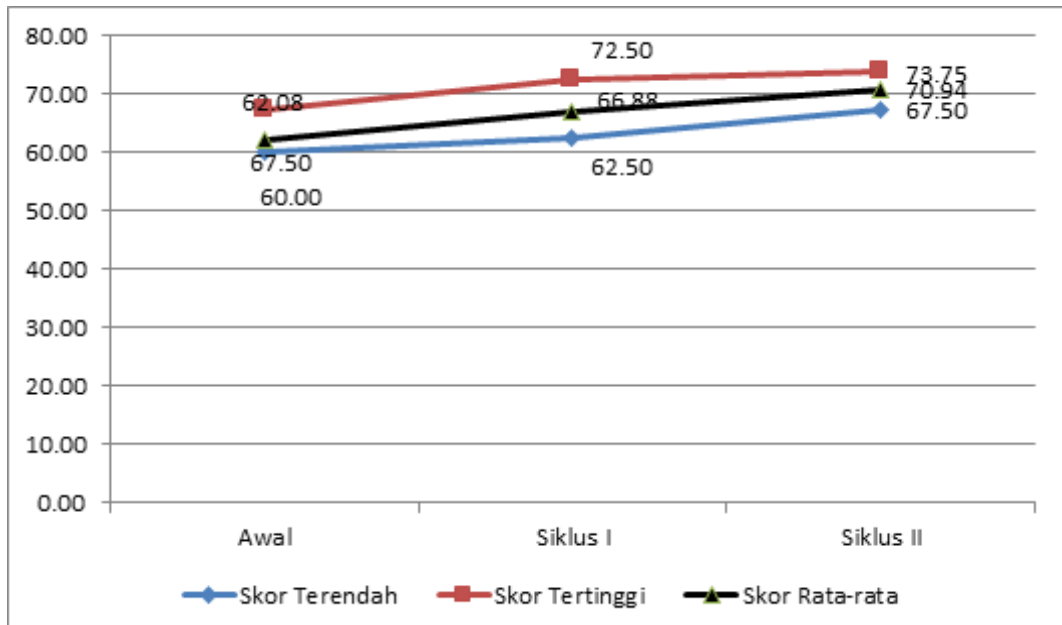

Gambar 2. Diagram Skor Kemampuan Guru dalam Penyelenggaraan Layanan Bimbingan dan Konseling

Supervisi kelompok metode direktif yang dilakukan oleh Pengawas Sekolah dalam pembinaan guru dengan materi layanan bimbingan dan konseling pada guru kelas di Gugus IX Dhandhanggula UPTD Dikpora Kecamatan Jebres Kota Surakarta dianggap berhasil dalam meningkatkan kemampuan guru kelas dalam menyelenggarakan layanan bimbingan dan konseling. Hal ini ditunjukkan dengan meningkatnya ketuntasan penguasaan penyelenggaraan layanan bimbingan dan konseling pada tindakan Siklus II.
Supervisi kelompok metode direktif yang dilakukan dengan simulasi ternyata dapat meningkatkan ketrampilan dan kemampuan guru dalam melaksanakan layanan bimbingan dan konseling. Pendekatan langsung adalah pendekatan terhadap masalah dengan cara langsung.

Supervisor atau kepala sekolah mengadakan supervisi secara langsung, prinsip yang dilakukan adalah menjelaskan, menyajikan, mengarahkan, memberi contoh dan menguatkan. Teknik supervisi secara 
langsung ini bisa bersifat: (1) individual seperti kunjungan kelas, observasi kelas, percakapan pribadi, intervisitasi, menyeleksi berbagai sumber yang digunakan untuk mengajar dan melihat cara dan hasil evaluasi; (2) kelompok yaitu pendekatan yang dapat dilakukan dengan bentuk-bentuk rapat guru, panitia penyelenggaraan kegiatan sekolah, studi kelompok guru/KKG sekolah, dan workshop. Pemberian contoh yang dilakukan melalui bentuk simulasi dan praktek langsung akan dapat meningkatkan kemampuan guru dalam materi yang disajikan. Hal ini sesuai dengan konsep kepengawasan itu sendiri yang bertujuan untuk membantu guru, yaitu bahwa Dalam melaksanakan tugas pokoknya, pengawas satuan pendidikan berfungsi sebagai pengawas pendidikan baik pengawas akademik maupun pengawas manajerial (Depdiknas, 2006: 3). Sebagai pengawas akademik, pengawas satuan pendidikan bertugas membantu dan membina guru dalam meningkatkan kemampuan profesionalnya agar dapat meningkatkan mutu proses dan hasil belajar siswa. Sedangkan sebagai pengawas manajerial, pengawas satuan pendidikan bertugas membantu kepala sekolah dan seluruh staf sekolah agar dapat meningkatkan mutu penyelenggaraan pendidikan pada sekolah yang dibinanya.

\section{Simpulan}

Berdasarkan hasil penelitian dan pembahasan hasil tindakan, penelitian ini menyimpulkan sebagai berikut:
1. Pelaksanaan supervisi kelompok metode firektif dalam meningkatkan layanan bimbingan dan konseling bagi guru kelas di Gugus IX Dhandhanggula UPTD Dikpora Kecamatan Jebres Kota Surakarta pada tahun pelajaran 2011/2012 dilakukan melalui langkah-langkah sebagai berikut: a.) Penyampaian informasi kepada guru tentang akan dilaksanakannya program supervisi kelompok; b.) Menyusun jadwal pelaksanaan program supervisi kelompok yang hendak dilaksanakan; c.) Penyampaian materi tentang program layanan bimbingan dan konseling; d.) Melakukan simulasi layanan bimbingan dan konseling sejak tahap perencanaan hingga evaluasi; e.) Melakukan penilaian terhadap kemampuan guru dalam melakukan layanan bimbingan dan konseling sejak tahap perencanaan hingga evaluasi.

2. Supervisi kelompok metode direktif efektif dalam meningkatkan layanan bimbingan dan konseling bagi guru kelas di Gugus IX Dhandhanggula UPTD Dikpora Kecamatan Jebres Kota Surakarta pada tahun pelajaran 2012/2013. Hal ini ditunjukkan dengan meningkatnya kemampuan guru dalam setiap aspek penilaian pada setiap siklus tindakan yang dilakukan.

\section{Daftar Pustaka}

Arikunto, Suharsimi. 2002. Metode Penelitian: Suatu Pendekatan Praktik. Jakarta: PT. Rineka Cipta.

Arikunto, Suharsimi, 1988. Dasar-Dasar Evaluasi Pendidikan. Jakarta: Bina Aksara.

Danim, Sudarwan. 2006. Agenda Pembaruan Sistem Pendidikan. Yogyakarta: Pustaka Pelajar.

Depdiknas. 2005. Standar Nasional Pendidikan. Jakarta: Direktorat Pendidikan Lanjutan Pertama Dirjen Dikdasmen.

Depdiknas.2008. Penataan Pendidikan Profesional Konselor dan Layanan Bimbingan dan Konseling dalam Jalur Pendidikan Formal. Jakarta: Depdiknas. 
Komnas Pendidikan. 2004. Peningkatan Kualitas Pendidikan. Jakarta: Komisi Nasional Pendidikan.

Marsudi, Saring., Rubino Rubiyanto, Sunarjo, dan Darsinah. 2003. Layanan Bimbingan Konseling di Sekolah. Surakarta: UMS Press.

Mulyasa. 2003. Manajemen Berbasis Sekolah: Konsep, Strategi, dan Implementasi. Bandung: Remaja Rosdakarya.

Mulyasa. 2005. Menjadi Guru Profesional.. Bandung: Remaja Rosdakarya.

Purwanto, Ngalim. 2003. Administrasi dan Supervisi Pendidikan. Bandung: PT. Remaja Rosda Karya.

Sahertian, Piet A., 2004. Konsep Dasar \& Teknik Supervisi Pendidikan Dalam Rangka Pengembangan Sumber Daya Manusia. Jakarta: Rineka Cipta.

Siagian S.P. 2005. Kiat Meningkatkan Produktivitas Kerja. Jakarta: Rineka Cipta.

Sofiati. 2002. Pemberdayaan Pengawas TK/SD dalam Menunjang Otonomi Bidang Pendidikan di Kota Yogyakarta. Tesis. Tidak Diterbitkan. Universitas Negeri Yogyakarta. 